\title{
Impact of priming techniques on germination, vigour, growth and survivability of drumstick (Moringa oleifera L.) variety PKM-1 under open and protected condition
}

\author{
Swati Barche*, Dharmendra Singh Dodiyar ${ }^{1}$ and Kamal Singh Kirad ${ }^{2}$ \\ Department of Horticulture, College of Agriculture, Rajmata Vijayaraje Scindia, \\ Krishi Vishwa Vidyalaya, Indore (M.P.) India \\ (Email: sbkdap07@rediffmail.com)
}

\begin{abstract}
The present investigation was carried out in Kharif season 2017-18 at the Horticulture nursery and dry land research farm College of Agriculture, Indore (M.P.) to study the germination, physiological parameters, biotic stress susceptibility, survivability per cent, as influenced by different condition and priming. The experimental materials for the present investigation was practiced with factorial experiment in Completely Randomized Design replicated thrice with different combinations of condition and priming. Condition and priming $(\mathrm{CxP})$, the treatment combination $\mathrm{C}_{1} \mathrm{P}_{6}$ (Open x Hormonal Priming Gibberellic acid @ 2000 ppm) maximum germination percentage, physiological parameters, survivability per cent, economics while treatment combination $\mathrm{C}_{2} \mathrm{P}_{1}$ (Protected $\mathrm{x}$ Unprimed) recorded with minimum results in terms of all the parameters except in incidence of pest per cent.
\end{abstract}

Key Words : Drumstick, Priming, Open, Protected condition, Germination, Vigour, Growth, Survivability

View Point Article : Barche, Swati, Dodiyar, Dharmendra Singh and Kirad, Kamal Singh (2020). Impact of priming techniques on germination, vigour, growth and survivability of drumstick (Moringa oleifera L.) variety PKM-1 under open and protected condition. Internat. J. agric. Sci., 16 (2) : 170-174, DOI:10.15740/HAS/IJAS/16.2/170-174. Copyright@ 2020: Hind Agri-Horticultural Society.

Article History : Received : 27.03.2020; Revised : 30.04.2020; Accepted : 06.05.2020

\footnotetext{
* Author for correspondence :

${ }^{1}$ Department of Horticulture, College of Agriculture, Indore (M.P.) India

${ }^{2}$ Krishi Vigyan Kendra (RVSKVV) Dhar (M.P.) India (Email: kskal24@rediffmail.com)
} 